\title{
INTRODUCTIONARY ARTICLE
}

\section{POWER AS KNOWLEDGE. THE REVERSE LOGIC OF THE POST-SCIENTIFIC WORLD}

\author{
ALEKSANDER KOBYLAREK \\ Institute of Pedagogy, University of Wrocław \\ J. Wł. Dawida 1, 50-527 Wrocław, Poland \\ E-mail adress: aleksander.kobylarek@gmail.com \\ ORCID: https://orcid.org/0000-0002-4562-9035
}

\begin{abstract}
This article deals with the causes and effects of a surrender to anti-science in social development. Populist governments support the idea of anti-science in an attempt to win over poorly-educated electors. The text analyses the fundamental characteristics of the pressure mechanisms adopted by populist movements, and points to the system of measures in various spheres which help in fostering general ignorance and support anti-scientific operations. For the agents of power science, and the system of values which accompanies it, becomes a target to attack. Simultaneously, for the average person scientific knowledge ceases to be the basis of analysis and interpretation of different phenomena. Anti-science regimes support antiscience movements in order to manipulate society and disrupt potential opposition. This is possible thanks to superficial education and not enough emphasis on critical thinking within the education system, because less discerning citizens will go along with an anti-science regime.

Analysis leads to the conclusion that the narrow short-term material interest of the regime is its only value, to which all others are subordinated, including Plato's triad. In the face of a lack of understanding on the part of the authorities, education based on episteme is not possible, at least not entirely. This article suggests the need for change in the philosophy of education to one where the major emphasis is on quality and prioritised content.

Key words: Demokratur, post-scientism, stupefaction, government by ignoramuses, publicness, critical thinking.
\end{abstract}

The Latin aphorism that "knowledge is power" describes the principle by which a rational society develops. Thus, knowledge constitutes the fuel for development, and at the same time we assume that mankind will strive to discover, understand and explain the world in a natural way. Additionally,

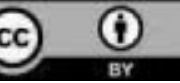


we express our conviction that we are striving to broaden our comfort zone (Jashapara, 2004).

We learnt this at school before concepts of knowledge management, education models, and the notion of habitus and social capital arose. Until then, the point of education in fact depended on introducing people to human achievement by creating a certain developmental continuum - from the most basic and simple forms of human activity to those more sophisticated, complicated, elaborate and even useful. In other words, development was perceived as linear until postmodernism seemed to be something obvious and irrefutable (de Solla-Price, 1963).

In the case of technology and the pure and natural sciences, based on logic and experiment, potential discussion of the facts was pointless, because on the whole they could be quickly proved by experimentation and verification, which are better at depicting our world. The criterion of truth sends us back to evidence, causality and pragmatic ingenuity (Sokal \& Bricmont, 1998).

In the case of the humanities and social sciences, conflict, disagreement, negotiation and bargaining have for centuries been written into their fabric, although this concept itself is not so old. By contrast, periods when one idea dominated and attempts were made to impose it on everybody led to expressions of hatred and contempt for others. After all, we are proud of the Greek schools of philosophy, the Sicilian School of Translators, universities, and American cultural anthropology as a theoretical reflection on cultural crucibles. On the other hand we are not proud of crusades, wars, fascism, authoritarian regimes or inquisitions. At least that is how it had been until now, because at the beginning of the $21^{\text {st }}$ century it suddenly turned out that what we learnt at school as elements of basic science could be questioned and undermined by the masses, and that science itself could be treated as a metanarrative equal to any other metanarrative. What was once one concept of the development of science has now become painfully real (Foucault, 1966).

Under anti-science regimes, the attack on rationalism and the scientific community comes from two different directions. One of these is the net society, where the advantage is taken by trolls, bots, propagandists and common morons, appearing as so-called beneficial idiots. They do not constitute the majority, but are the most visible through their effrontery, aggression and specific way of expressing their opinions through radicalism, intransigence and an unshakeable conviction that they are right. The majority of those behind such false statements are people who are confused, ill-educated, misinformed and lost in reality, or who have a problem not only with critical thinking but also even the logical linking of information and association between facts (Andreski, 2002, Pietrzyk, 2019). However, they are not the only ones functioning in this group. Trouble-makers, a certain kind of lords of chaos, and expert manipulators who for small short-term material benefits (paid trolls) either for fun or for strategic goals (as, for example, the fake news and anti-European campaigns used before the EU referendum in the UK) construct a simulacrum of reality (Baudillard, 1988). They are totally conscious of their actions, but completely 
unaware of the long-term consequences. In both cases, the actions of such people should be called stupidity, because not only do they not minister to the truth, but they also destroy trust and in the long run are acting to the disadvantage of large communities such as the state (in the case of political simulacra) or humanity (in the case of simulacra of nature and medicine (Batelle, 2006). Thus, there are both wolves and blind ignorant sheep in the same pack.

The second front in the war against rationalism is presented by governments supported by ideology. In democracies where the road to politics is long and recruitment demanding, the authorities try to take care of the interests of society, variously defined. In societies where it is possible to become part of the political elite from any social position, often accidentally, there is a greater probability of the existence of reverse dependence between knowledge and power.

In well-functioning democracies the members of the regime respect science and use its achievements to improve the living conditions of the electorate. The reverse logic of undemocratic societies and quasi-democratic demokraturs (Kobylarek, 2020) depends on the auto presentation of power as knowledge. In this case the political elite reserves the right to their own interpretation of facts, relationships, scientific laws and theories. Conviction of their own infallibility, characteristic of the poorly educated, coupled with an ostentatious demonstration of power towards everything in general and the world of science in particular, is probably supposed to invoke the impression, or even conviction, that the representatives of power are somehow imbued with some kind of general knowledge which is inaccessible to others. However, in reality anti-science declarations seek to justify irrational, illegal, or at least immoral, behaviour in communities (national or universal).

The simulacrum of an all-knowing regime, so easy to deconstruct for the scientific community, becomes totally destructive for intellectuals and communities. It seems to poorly educated people that only a populist government which falsifies facts can represent them, because it is easiest to copy their simplified vision of the world. The sheep become so deluded in that they believe that only the wolves can govern them in the appropriate way.

In the narrative of populist regimes, knowledge is replaced by an ideology which calls on beliefs, dogmas, stereotypes, religion and popular knowledge, and which has limited use and cannot be extrapolated from the environment in which it arose, and even more has neither suitable methodological support or scientific authority (Such \& Szcześniak, 2002). However, on the other hand it fills the deep-rooted need for social acceptance by those who are either intellectually or socially rejected. Those who have hitherto been told that they can't do anything, will never amount to anything and it's all their own fault, at last have a feeling of empowerment. Along comes a government which says that these excluded people are right and that they should be appreciated and maybe even treated better because of the years of deprecation that they have had to bear with shame. Anti-science regimes legitimise hitherto concealed conspiracy theories, stereotypes and convictions, raising 
them to the rank of absolute truths, standing as high as or higher than science in their hierarchy of values.

A government of non-scientific populism has no choice. It has to flounder around with a basically false narrative of a "common sense" approach to the world's problems, because explanations which are truly scientific have already been taken by their political opponents. They cannot afford to lose such a race, nor do they want to, so they have to take another path - a dishonest shortcut. Embracing a scientific perspective would condemn the leaders of populists parties to defeat, because they wouldn't be able to effectively appeal to the resentment of the disenfranchised or cover their subsequent dirty tricks with devious or reverse logic. However, taking ideology as their starting point allows them to awaken and foment resentment, throw the blame on arbitrarily created scapegoats, and in the end steer the awakened demons of hatred in the appropriate direction.

However, nothing can be built on anger and hate, even if it is on the backs of scapegoats - the Nazis discovered that sooner or later someone will oppose, someone will defend themselves, and finally someone will foot the bill. In the face of a growing wave of anti-science populism, however, there exists the real danger of total destruction.

\section{THE DECONSTRUCTION OF AUTHORITY}

Present scientific, political and moral authorities pose a serious threat to an anti-science regime, because by functioning in the consciousness of the social masses they contradict their narratives. Whether these authorities oppose the government or are merely threatening to is of no significance. The very possibility of opposition is already dangerous, that is why we very often see preemptive strikes to discredit authorities which are ideologically opposed to them. Thus, the destruction of existing authority is in effect directed at those which do not express approval of the government.

In the case of moral, religious, artistic and also scientific authorities, neither their output, nor achievements, nor their academic titles or position have any significance. Completely the opposite. The greater their achievements and powerful position, the greater the reason for taking destructive action against them. In the worst case scenario, when an authority is seemingly out of reach (a Nobel prize-winner, or an opinion former from an overseas organization), it is always possible to disregard their opinions and recommendations, on the principle that what can't be destroyed should be ignored.

An anti-science regime aims to replace these authorities with their own authority, at first as an alternative and later, more daringly, as the only authority. Here it is difficult to speak of the ideas and pure intentions of these newlycreated authorities. Rather, they ae recruited from among those who are full of resentment, as well as the electorate. They become loyal supporters of the government because in former systems their theories and visions were not under- 
stood or even able to reach the main-stream, acknowledged as weird, destructive or quite simply absurd. This type of authority rejoices in the fact that they are able to break a tradition which they were never able to be part of. A small percentage of them are high-class specialists, who want to make a career for themselves whatever the prevailing conditions. One could suspect that this is a kind of conformism by which they will be able to attain an important position in the political hierarchy. They only have to accept the reverse logic of the antiscience regime, in other words renounce methodology and scientific tradition, and if necessary betray themselves.

Obviously these artificial authorities, just like the post-science regime, totally ignore the opinion of those who are outside the government camp and present their own narrative as the only true one, by ideologically referencing "the law of nature", a specifically understood "civilization" and their own definition of "normality".

In effect, the process of destroying authority comes into being. Then new monuments to the new personal models dictated from the top are set up, and new narratives created which pretend to be historic, meaning a de facto distortion of history (Bobek, 2018). This process goes so far that in time the anti-science regime challenges accepted historical facts, or shows them in a completely different light, reserving to themselves the right to interpret events in their own way.

However, this deconstruction of authority effectively ends with the destruction stage. Nothing new is created to replace it, because the new authorities are of doubtful quality and educated people remember the real history and are sceptical to that which has been newly created. They resist the anti-science propaganda, but some of them can begin to doubt and succumb to manipulation. Thus, there is a danger that the longer a new anti-science regime lasts, the greater the probability of logic being replaced by pseudo-logic and facts by simulacra, leading to universal uncertainty.

\section{THE DECONSTRUCTION OF LANGUAGE}

The words used by the representatives of a post-scientific regime have new meanings and refer to totally different contexts than earlier. For the new elite it appears that meaning has first and foremost the (magical) function of determining language. By using it in a specific way they create a new reality for themselves, and others must accept their vision of the world without discussion. Language is used by the anti-science regime as a means of one-way communication. Agreement over meaning, negotiation, mediation and settlement are practically impossible because for the regime there is only one vision worth carrying out and the rest have no meaning, so there is nothing to agree upon. Thanks to its magical function, language becomes a means of exercising power. An anti-science demokratur is accomplished by imposing its own language and own non-negotiable interpretation of meanings. 
There are real doubts as to whether an anti-science regime is at all able to accept the fact that it is possible another vision of the world exists apart from its own. Perhaps some of the more cynical of its representatives are aware of other systems of meaning, but this doesn't concern them as long as it doesn't threaten the accomplishment of their vision. In case of threat, they will aim to eliminate or at least discredit all other meanings.

One way or another, exchange of thought and respect for the interlocutor (Buber, 1999) is impossible in the case of anti-science regimes. In the face of arbitrarily established positions which resemble a system of illogical dogmas, it is impossible to reach any kind of agreement in the traditional sense. By using its own logic, the anti-science regime can only be "convinced" by the argument of force. To the representatives of deliberative democracies, accustomed to political agreement, it appears (falsely) that any kind of settlement is possible (March \& Olsen, 1989). At the same time an anti-science regime will never acknowledge arguments which for them are uncomfortable. Its representatives are able to utter total nonsense and pronounce statements deprived of any kind of scientific basis as long as they can, that is, as long as they don't come up against hard opposition by certain communities, the pacification of which would carry too high a cost. On the other hand, lies are repeated for propaganda purposes for so long that in the end they are recognised as the one and only possible and real truth.

Science is closely connected with the concept of episteme. We conduct science in the conviction that it should serve everybody. Meanwhile, anti-science demokraturs are interested in the dox and techne types of knowledge (Kobylarek, 2007). Science should fulfil an ancillary role and is of course perceived in the perspective of civilizational achievement as something which, like every tool, can be used to eliminate or restrict the rights of those who are not "right thinkers". Anti-science regimes are characterised by an ethnocentric perspective, whereby they themselves decide who belongs to the ethnos and who is a discreditable alien element which should be eliminated. In this connection it creates integrated institutions (March \& Olsen, 1989), which will carry out a politic based on the values of a strictly defined society.

An anti-science demokratur often refers to national community values by showing these values by examples which are often illogical and outside any kind of rules. It is also an ostentatious form of presentation of power over concepts, language and people by calling on the magical function of language. The regime not only defines what is theirs and what is alien, but it also presents a kind of certificate of origin and morality with reference to specific representatives. This means that we are dealing with a kind of cultural revolution (a cultural civil war) in which the victims are the weak and minorities, whose voice is less audible in the social space. Such values as cultural heritage, civilization, justice and the good of the people cease to have the meaning they had up to now, and are either interpreted to the benefit of the regime or rejected altogether. Referencing them is beneficial in order to create a veneer of acting in good faith. 
In this chaos and confusion concerning concepts and values, there is one which is dominant and unchangeable. It is the feeling of injury and resentment which fuels the anti-science regime. However, nobody talks about it and it becomes a hidden agenda which has particular significance in shaping education (Meighan, 2007).

If, however, resentment and a need for revenge for some real or imaginary hurt somehow become a primary value, then we are not able to build anything. We can only demolish what we have or subject it to never-ending deconstruction. In time, such a regime will come up against an ever-increasing number of social groups and will ignore, undermine and deprecate all that those groups which are under attack hold dear.

\section{THE DECONSTRUCTION OF THE COMMUNITY}

Anti-science regimes do not recognize the concept of a people's community or universal values. For them, only nations and predetermined groups exist. From the perspective of the group holding power, other groups can only fulfil an auxiliary role in realizing their goals, always taken as a priority, and from the national perspective other nations can only be supportive, without taking part in decision making.

In turn, a community built by the anti-science regime is first and foremost a community of interest and specific measures dedicated to defending their own interests. Breaking out of such a community means betrayal. Remaining inside the community means sharing the benefits and advantages which flow from the wielding of power and the deprecation of "the other". Therefore, the concept of "the good of the people" cannot exist in the imagination of the anti-science regime because it can only be defined with reference to the specific material benefits of the regime. The activities of anti-science demokraturs paints a picture of other social groups as losers and dupes which need to be fleeced, denigrated, downgraded, deprived of dignity or taken advantage of as long as possible, based on their weakness and stupidity. Language, symbols and values have meaning only insofar as they can be taken advantage of in manipulating social groups. The concept of nation - a real Pole, American or Englishman can be freely redefined according to how it suits the anti-science regime. If it suits the regime, Coronavirus either doesn't exist, or is non-threatening, but it is fatally dangerous if the regime sees in it profit or if its image is damaged by the revelation of its deceit (as in the case of Boris Johnson, Donald Trump, Jair Bolsonaro, and in Poland). At the same time the anti-science regime wishes to present itself as a voice for the "ordinary man", defined by the regime as an under-educated fool who remains sceptical in the face of viruses which he can't see, or the effects of vaccination. Naturally, all intellectuals, specialists, and everybody else who deals with knowledge, must be excluded from this community because they are the natural enemies of ignorance. Perhaps some of these enemies will go along with the proposed narrative and become allies 
of the anti-science demokratur, at the same time betraying their intelligence for material benefits.

Therefore, the only community in the understanding of an anti-science regime is a community of submissive idiots and their accomplices. The first can easily be deceived and second can be cynically taken advantage of. Others have no right to exist and at the most can only be tolerated. This is borne out by the stubborn pursuit of the regime's own aims with neither discussion nor negotiation, the uttering of complete nonsense, and the substantiated actions taken in bad faith against its own nation and people. For the regime, legitimization through election means permission to carry out its arbitrary programme, without asking for the opinion of others and without taking into account any superior arguments.

\section{THE DECONSTRUCTION OF THE ESSENCE OF EDUCATION}

The actions of an anti-science regime are destructive for education in many ways and on every level.

Above all, popular knowledge acquires the same status as science. The members of the regime frankly excel themselves in propagating anti-science views, creating the impression that it is possible to choose our own truth or that the nonsense supported by the regime is the one and only irrefutable truth. In such a community intellectuals and workers with knowledge become superfluous, like some kind of unnecessary flower pinned to a sheepskin coat or an ox harnessed to an ambulance. They can be ignored and their opinions disregarded (Collins, 2014).

If there are no independent authorities and everyone can become a new authority, then the positions of teachers and researchers is also weakened. Educational content depends on verification by leading ideologists who take care to present the "right" perspective when it comes to the interpretation of facts and events.

In turn, arbitrary manipulation of facts and events offends the intelligence of those working with knowledge, who must bear the excesses of stupidity with humility.

Is it possible, however, to negotiate anything with an anti-science regime which sees no need for negotiation? And this especially in the situation where someone is a real worker with knowledge who generally comes from outside the regime's system. The answer appears to be obvious. It appears that the moment has come when we are left staring at a catastrophe. The skyscraper is wobbling and there is nothing we can do about it. We can see this, but the "ordinary" citizens, enchanted by anti-science balderdash, can see nothing. Some of them will be killed by the catastrophe caused by the anti-science regime, and some of them will wake up in the ruins and start looking for an explanation as to how and why it happened.

If we can't avoid the catastrophe at least let us be ready for it in any way we can. Some time it will be necessary to clear away the rubble, settle with the 
amateurs and start to rebuild when the time for building comes. Just as fascism gave us a painful lesson, in the same way we should analyse how did it happen that in a certain moment mankind became stupid. Perhaps we have never been sufficiently developed to see the most important problems from an appropriate perspective. Maybe we were too indulgent towards ignorance and handed out degrees to under-educated ignoramuses, giving them the right to take the most important decisions, and who are now proudly brandishing their degrees and spouting utter nonsense. Maybe we educated people beyond their ability. Maybe amateurs were educated by other amateurs with scientific titles who for various reasons could not resist helping others who didn't deserve promotion (Błaszczyński, 2013). From here it's a short step to the conclusion that the impulse came from the intellectual community, which initiated the creation of social stupidity. The first amateurs with degrees were educated by others who were over-lenient and careless, not to say lazy dogsbodies of knowledge (Kobylarek, 2016).

If this is true, we should reject the dilemmas of post-modernism and postscientism and return to basics in the form of Plato's triad of Truth, Beauty and Goodness. Later, we can slowly build the correct order and hierarchy. How this can be done is the subject of another analysis, however, the basis of the scientific system of education certainly cannot be reformed without separating the feudalists and amateurs from the experts (Kobylarek, 2017), and putting science and the good of the people over the good of individuals who form a narrowly-defined sphere of interest.

\section{REFERENCES}

[1] Andreski, S. (2002). Czarnoksięstwo w naukach spotecznych [Witchcraft in the Social Sciences]. Warszawa: Oficyna Wydawnicza.

[2] Battelle, J. (2006). The Search: How Google and Its Rivals Rewrote the Rules of Business and Transformed Our Culture. Boston-London: Portfolio.

[3] Baudrillard, J. (1988). Selected Writings. Stanford: Stanford UniversityPress.

[4] Błaszczyński, K. (2013). Zmierzch bogów - o zasadności likwidacji habilitacji i profesury w Polsce i krajach europejskich [The twilight of the Gods - on the validity of the abolition of habilitation and professorships in Poland and European countries]. Ogrody Nauk i Sztuk(3), pp. 54-63.

[5] Bobek, B. (2018). Polityka historyczna Węgier. Współczesne oblicze [Historical policy of Hungary. Contemporary countenance]. Ogrody Nauk i Sztuk(8), pp. 128-136.

[6] Buber, M. (1999). Ich und Du. Gütersloh: Gütersloher Verlagshaus.

[7] Collins, H. (2014). Are we all scientific experts now? Cambridge: Polity Press.

[8] de Solla-Price, D. J. (1963). Little Science, Big Science ... and Beyond. New York: Columbia Univ Press.

[9] Foucault, M. (1966). Les mots et les choses. Une archéologie des sciences humaines. Paris: Gallimard.

[10] Jashapara, A. (2004). Knowledge Management: An Integrated Approach. Essex:Pearson Education.

[11] Kobylarek, A. (2007). Episteme i doksa w późnej nowoczesności [Episteme and dox in post-modernism]. Pedagogika Szkoły Wyższej(30), pp. 57-69.

[12] Kobylarek, A. (2016). Seven cardinal sins of science. Journal of Education Culture and Society(2), pp. 5-8.

[13] Kobylarek, A. (2017). Polish Humboldtian University in the Face of Paradigmatic Change. Cambridge Scholars Publishing. 
[14] Kobylarek, A. (2020). The pedagogy of shame. Education in the face of the demokratur of ignoramuses. Journal of Education Culture and Society(1), pp. 5-12.

[15] March, J. G., \& Olsen, J. P. (1989). Rediscovering Institutions. New York: Free Press.

[16] Meighan, R. (2007). Sociology of Educating. London: Continuum.

[17] Pietrzyk, A. (2019). Kulturowe spojrzenie na programy powszechnych szczepień ochronnych wczoraj i dziś [Cultural Perspectives on Vaccination in the past and present]. Ogrody Nauk $i$ Sztuk(9), pp. 113-132.

[18] Sokal, A., \& Bricmont, J. (1998). Fashionable Nonsense: Postmodern Intellectuals Abuse of Science. New York: Picador

[19] Such, J., \& Szcześniak, M. (2002). Filozofia nauki [The philosophy of science]. Poznań: Wydawnictwo Naukowe UAM. 